\title{
THE EMERGENCE OF NEW MEDIUM
}

\author{
Siti Susanti Mallida Djaha, S.S., M.A \\ susantidjaha@gmail.com
}

\begin{tabular}{|c|c|}
\hline Article Info & ABSTRACT \\
\hline $\begin{array}{l}\text { Article History } \\
\text { - Article Received } \\
5^{\text {th }} \text { March } 2019 \\
\text { - Article Reviewed } \\
8^{\text {th }} \text { March } 2019 \\
\text { - Article Accepted } \\
29^{\text {th }} \text { March } 2019 \\
\text { Keywords } \\
\text { Edwardian Era } \\
\text { Drama } \\
\text { Theater } \\
\text { New Medium } \\
\text { Movie }\end{array}$ & $\begin{array}{l}\text { This study aims at finding the development of new medium of drama in English } \\
\text { literary history. From the very first emergence of drama, the plays that have been } \\
\text { written were performed in the theater and in many kinds of theater were appears to } \\
\text { represent some ideas from the society. As time passing by, these kind of theater had } \\
\text { a kind of transformation to be the new medium that we called motion picture. This } \\
\text { motion picture began with the silent movie, then it became the talking picture, and } \\
\text { it was improved to be the cinema. In its development until today, which we had } \\
\text { been known as the movie. This new medium emerged to replace the live theater } \\
\text { performance especially in Edwardian era. }\end{array}$ \\
\hline
\end{tabular}

\section{INTRODUCTION}

The reign of King Edward after the Queen Victoria died in 1901 achieved success in many parts of life in Britain society. King Edward led the United Kingdom with marked the start of new era and the end of Victorian Era, even though he only reigned about ten years, but he succeeded to make a vast change in this era. As [1] said in his book Twentieth Century British Drama:

When Queen Victoria died in 1901, Britain ruled the largest empire the world had ever seen. A quarter of the world's population was under British rule and the British navy ruled the sea. The Industrial Revolution had put Britain ahead of its European rivals and allowed it to become the largest trading nation and banker to the world. It seemed to some that this golden summer could never end [1].

However, [1] added that even though the Industrial Revolution brought many great inventions of the 19th century, there were still underlying problems. For instance, in social conflicts such as the gap between the poor and the rich, the owner of the industrial market and the labors. Beside their great inventions, all of the focus were on industry. In a competitive market that increasing so fast, the relationship of workers or the labor and their board of Director came under tension. The workers were paid with the same wages when the price went up and the industry became larger. Between 1910 and 1912 there were strikes by dockers, miners, and railwaymen. Besides, women sufferings and their struggle to gain their vote right were also become the main problems in that era.

Women suffragette movement transformed their political protest into a campaign of violent action. Thus it became the context in which Repertory Theatre was established. Repertory Theatre was a kind of theatre that established to bring society's problem to the audience attention and gave voice to the underclass. It is first established by Miss Horniman in 1904 (Postlewait in [2]). Horniman built a repertory company called Manchester school which represented 
working class life with a sympathy and a humor born of close observation [1]. Kennedy added that The Manchester School is the clearest sign from the repertory movement that the regions were providing something new and much more populist than the London theatre (Kennedy in [2]).

Another theatre also established in this era was Agit-Prop theatre. Agit-prop theatre was a short for agitated propaganda. It was a kind of theatre used to 'disturb' the public into action about a certain political or social issue. Theatrical in their protests, sometimes even wearing the arrowhead costume of convicts, the suffragettes used the resource of drama to the full [1]. In general, they wrote plays and produced theatrical events tended to rely on conventional dramatic forms and concentrated on one political issue, that was the vote (Carlson in [3]). Agit-prop theatre was more developed when the campaign of suffragette movements was exploded.

Based on the historical background above, this study aims at finding the emergence of new medium of drama. This new medium considered as the initial stage in the development of British theater.

\section{LITERATURE REVIEW}

\section{History of Drama Development}

In this study, the writer uses historical criticism approach to discuss about the emergence of the new medium in Edwardian Era. Historical criticism seeks to understand a literary work by investigating the social, cultural, and intellectual context that produced it - a context that necessarily includes the artist's biography and milieu [4]. This approach is used to find about the history of drama development in Edwardian Era, Edwardian theatre as the basic information of the motion picture development.

\section{a. Drama in Edwardian Era}

Apart from the problems that emerged at that time, the development of drama in this Edwardian Age underwent enormous improvement. In 1890, the first series of Edwardian musical comedies were introduced to the country. Edwardian musical comedies delighted a generation with their carefree atmosphere, robust humor and sophisticated but catchy melodies [5]. Edwardian Musical comedies came out to change Gilbert and Sullivan's- a theatrical partnership- dominance of operas. The founder of Edwardian musical comedies was George Edwardes. He made an improvement of the old burlesque and experiment with modern style of musical. The first Edwardian Musical Comedy that produced was "In Town" (1982) and the last was "The Maid of the Mountains"(1916) [5].

As the result of this Edwardian Musical Comedies, more and more people started to come to the theatre. It can be said that drama had been a profit business and the increased of the audience affected to the production of drama. It also influenced the emergence of many composers in this genre such as Sidney Jones "The Geisha", Ivan Caryll "Our Miss Gibbs", Howard Talbot "A Chinese Honeymoon", Leslie Stuart "Florodora", Paul Rubens "Miss Hook of Holland", and the most popular of all was Lionel Monckton "The Quaker Girl” [5].

Edwardian Musical Comedies were shown with their best musical scores. Charlton [5] added his opinion that these musical comedies combined the delicacy and sophistication of operetta with the robust tunefulness of the musical hall. Unfortunately, these Edwardian Musical Comedies did not last long, and soon replaced with American musical theatre and comedies. It is brought by Noel Coward, Ivor Novello and their contemporaries which were shortly replaced the Edwardians. Noel Coward known as the cleverest of living English dramatist, while Ivor Novello was one of the most successful British composers/performers. Both of them gained their popularity from the period of 1920 s. It was during the time of the emergence of new medium which was called motion picture.

Furthermore, English musical theatre in Edwardian era was formed in comic operas that with a modern-dress, popular songs, snappy or stylish fashion, their plots were simple and included elaborate displays of contemporary fashion and scenery, and light parody of social convention and topical issues [6].

Meanwhile, American musical theatre in the late nineteenth century and twentieth century was also formed in an attractive way. It included glamorous and handsome actors and actresses, catchy or sentimental songs, elaborate-stage effects, dialogue filled with plays on words, and a highly acting style that was developed in parallel with melodrama and pantomime (Riis in [7]). Therefore, the difference between English and American musical theatre might be seen from the technique they used at that time, where American musical theatre already had high acting style compared with English musical. In addition, the issue they used in their theatrical events still explored about the life of 


\section{neTIOn}

the lower class and also social convention that happened at that time.

\section{b. Edwardian Theatre}

The popularity of Shakespeare in Renaissance era was very influential on the development of drama in the next era. While most playwrights focused on only one of the themes, Shakespeare proved himself as a well-known playwright at that time by producing three kinds of drama including historical drama, comedy and tragedy. Moreover, this becoming a starting point to the dominance of drama in English Literature. As time goes by, the theme in the drama was also improved with several new ideas such as heroism and restoration comedy or comedy of manners in the Restoration Era, domestic tragedy and sentimental comedy in the 18th Century, etc. Besides, musical instrument is also already used in 18th century.

The development of drama was not only limited in written but also started to develop in a live theater with musical instrument. The musical burlesques and comic operas competed with the plays written by Shakespeare during the Victorian Era ("Lifestyle Lounge", 2013). Smart [1] said that Theatre in Edwardian times was essentially London-based and provided a sense of occasion for those who could afford it. Theatre in Edwardian Age consisted of two different classes:

\section{West End of London}

West End of London was the theatres for upper and middle class. These two high classes had an opportunity to see and be seen in splendid surroundings where ladies and gentlemen, dressed formally in evening dress and sat in ornately decorated comfort in of the grand theatres of the West End of London [1]

. They might see a Shakespearean comedy in which a naturalistic set of dazzling beauty earned a round of applause as the curtains opened or the Never-Never Land' of J.M. Barrie's Peter Pan (1904).

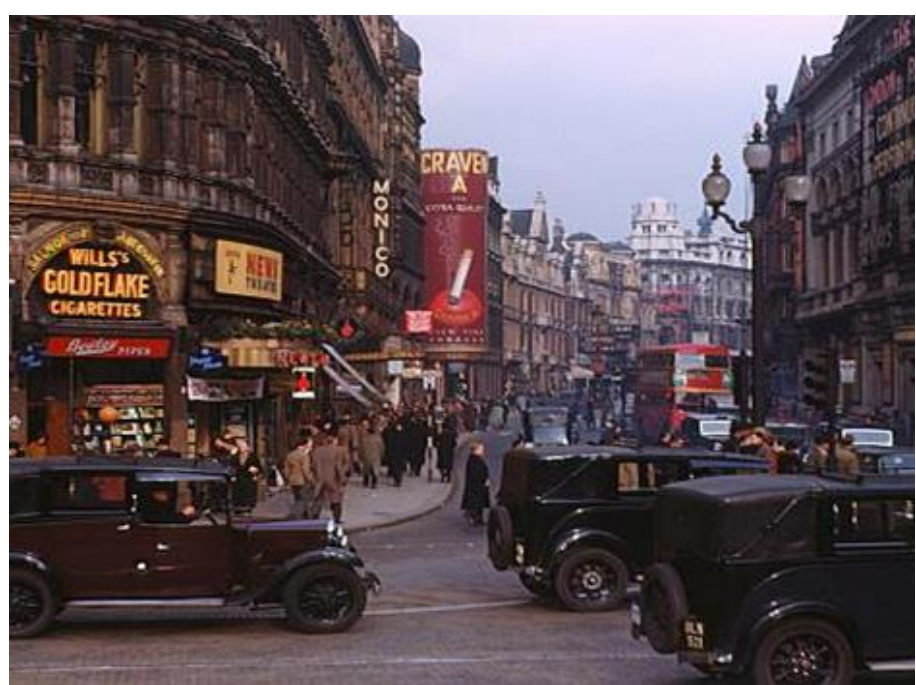

Picture 1. Theatreland in West End London

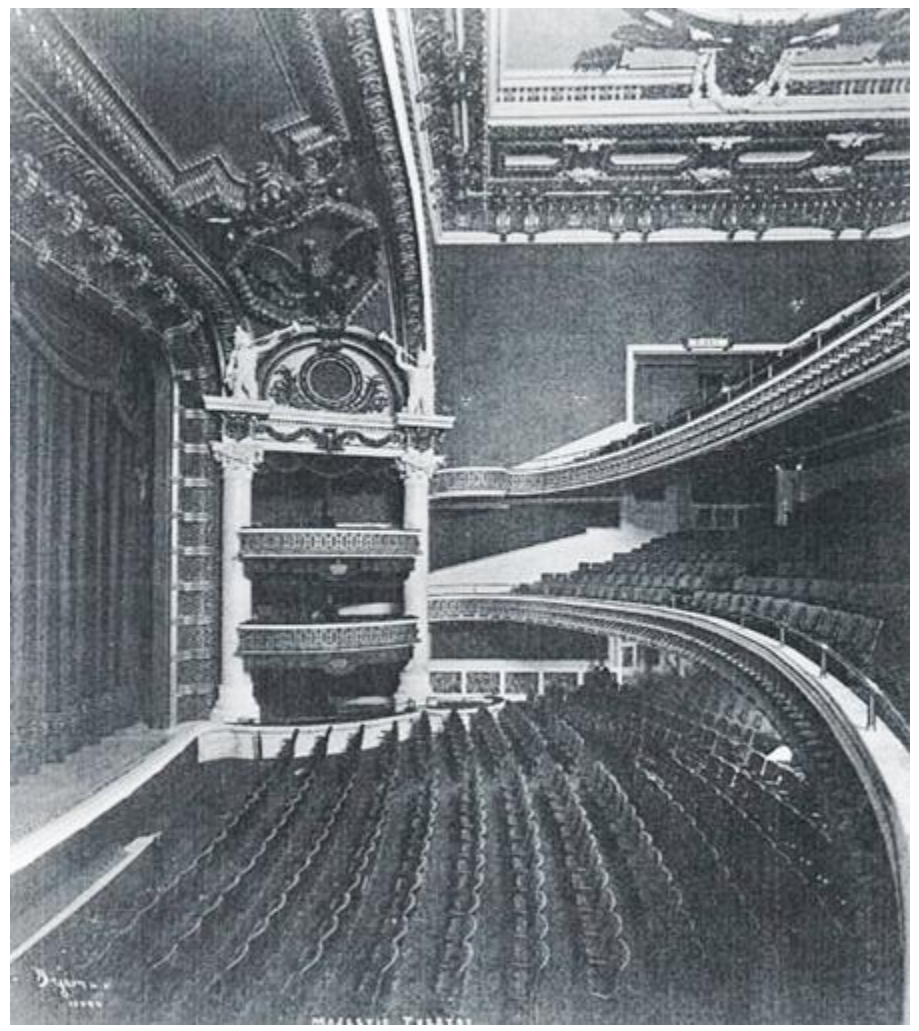

Picture 2. Coliseum Theatre in West End of London

In West End of London, the centre of the performance was the star himself that also led a role as the manager. The actor-managers controlled all the aspects in the theatrical system such as the payment, rehearsal, the responsibility for the theatre itself and of course led the main roles in the plays they directed. Postlewait in [2] explained that throughout the late Victorian and Edwardian eras, the West End establishment of actor-managers, lessees, impresarios and entrepreneurs controlled London theatre. 


\section{The Music Hall}

The working class had their own theatre in the music hall. The music hall also popular as national theatre flourished in London and throughout the country [1]. Their stars also became national legends such as Marie Lloyd, Dan Leno and Vesta Tilley. Their comedy told about romance and slapstick (humor) that pictured directly into the silent films. It brought a closer reflection of the lives of its audience that was dominance by the working class, but it softened by romance and brightened by humor. This comedy's stars such as Laurel and Hardy and also Charlie Chaplin.

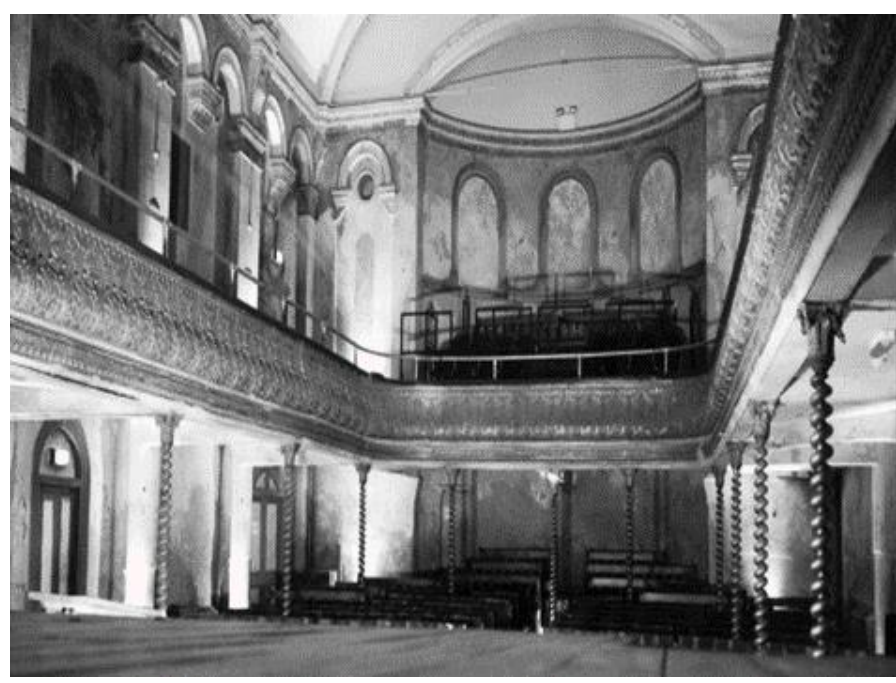

Picture 3. Music Hall of London

\section{METHODOLOGY}

\section{a. Method of Collecting Data}

This research employs library research method in order to collect the appropriate data needed in analyzing the topic. The data are collected from various sources, written materials, online articles and websites.

\section{b. Method of Analyzing Data}

This research carries out literary historical analysis since it deals with elements of literature especially drama. The work is analyzed in its historical background such as history of drama development. After depicting the social, cultural and intellectual facts at that time, the writer can conclude about the main concerned topics of the new medium.

\section{RESULT AND DISCUSSION}

\section{a. Emergence of New Medium and Its Characteristics}

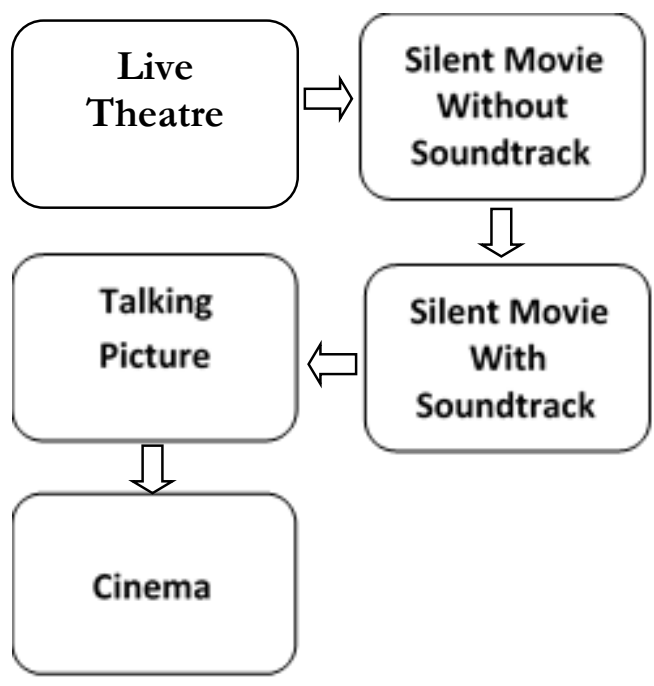

Figure 1. Emergence of New Medium

New Medium or motion picture emerged to replace the theatre performance in Edwardian Age. Motion picture containing silent movie was the very first movies that did not have soundtrack. Motion picture or nowadays known as movie was a kind of silent movies that contains of some clips in black and white movies. This motion picture's appearance slowly brought down the spirit of live theatre performance in London. Nevertheless, it was not become the end of the playwright's career, they still continued to exist though some of the dramatists started writing for the new medium.

During these movies, frames would appear that would give a clip of significant dialogue, or a short summary of the story at that point [8]. The characteristic of the early silent movie was often accompanied by live piano or organ music and provided enormous entertainment value to audience everywhere. Although various attempts had been made to introduce sound, it was not until 1923 that a commercially distributed film contained a synchronized sound track that was photographically recorded and printed on to the side of the strip of motion picture film [9].

Although the show of silent movies had existed for decades, yet the popularity of the motion pictures was exploded in the 1920s. It was almost six years after the World War I. The Great War of 1914 - 1918 divided two very different cultures, prosperous prewar and diminished postwar, seriously affecting the content of the drama, but the general British drama in its basic forms and techniques was not much affected 


\section{n TION}

(Dietrich, 2000). Moreover, the Great War killed more than half a million British soldier. It became the reason why the theatre shows were mostly dominated by comedy that full of humor because it aims at giving spirit to the victims of the First World War.

One of the most famous actor of the silent movie was Charlie Chaplin. He started his career as a comedian on the music hall in vaudeville, which eventually took him to the United State in 1910 as feature player with the Fred Karno Repertoire Company [10]. He is most recognized as an icon of the silent film era that associated with his popular "Little Tramp" character, the man with the tootbrush mustache, bowler hat, bamboo cane, and a funny walk. The content of the comedies still related to the daily lives that lightened with the funny side of the characters. Their essence was entertainment and made people laugh, made the world a happier place to live in after the horrors of World War I.

Furthermore, the development of silent movie had improvement became talking picture. In 1920s, films like the 'Jazz Singer' released with synchronized sound track made the critics assumed that the 'new medium' would soon replace live theatre [11]. The Production of the Jazz Singer in 1927 in America did much to change the industry's perception of talking pictures. This soon became the new and popular entertainment and the growth of "the talkies" in the late twentieth century stolen the live theatre's audience [12].

The new entertainment of Jazz Singer in America had another side in England where the Daily Mail coined the phrase 'the bright Young Things' Both referred to that post-war phenomenon of the young casting aside their parents' values and living their lives in new and daring ways [1]. It was assumed that the Great War affected the social change to not only the rich but also to the poor where they all faced the new world. Even the young people had to choose their own live and their own career.

Even though "The talkies" already gained their popularity, the British drama still hold tight their power. Noel Coward proved himself as the most famous man in England as the author of two plays The Vortex and Fallen Angels. He was the playwright and also the actor of the drama he had written. In The Vortex, Coward told about the social world of sexual desire and artistic pretension. Besides The Vortex, he also produced Hay Fever (1925) that according to him that was his best comedy. [1].
Along with the Jazz Singer in America, the talking picture then finally grew up became the cinema in 1930s and this became a powerful challenge to the theatre in England. Many Theatre were converted to cinemas. According to [1], in 1939, 20 million cinema tickets were sold each week, and cinema was able to reach out to a widespread and genuinely mixed audience. Cinématographe which was invented by Lumière brothers brought many effects and helped the expansion of cinema. Even music halls responded by including films as part of their bills (Kennedy in [2]). Cinema growth shortly in the early years because of the ability to create a place or something happened through photo-realism.

Besides, Kennedy added an opinion that the underlying reason for cinema's success with the popular audience was financial [2]. In fact, the cost of making a full-length film as much as the whole theatre production. Thus, cinema became popular in a short time and abducted the popular theatre's audiences.

\section{CONCLUSION}

The popularity of English Theatre was closed during the period of the Interregnum $(1649$ - 1660) from the Era of Queen Elizabeth to the Prince Charles II. The theatre was reopened after the Restoration of the Monarchy in 1660. By the time, the development of drama undertook metamorphoses from the written drama, then became live theatre performance such as musical burlesque and Edwardian Musical Comedy in Edwardian Age.

After that it was changed to the new form of drama show which was called the new medium or the motion picture. At first, this motion picture still formed in silent movie, slowly it was equipped with sound track, and finally had the last transformation to be a movie and cinema that officially had the talking pictures. In addition, the new medium was also fully affected to the change of social life in the world especially in England.

\section{REFERENCES}

[1] Smart, John. 2001. Twentieth Century British Drama. Barlow, Adrian, Ed. Cambridge University: Cambridge University Press.

[2] Kershaw, Baz, ed. 2004. The Cambridge History of British Theatre, Volume 3, Since 1895. Cambridge: Cambridge University Press. 
[3] Luckhurst, Mary, ed. 2006. A Companion to Modern British and Irish Drama, 1880-2005. USA: Blackwell Publishing.

[4] Kennedy, X.J and Gioia, Dana. 1995. Literature: An Introductions to Fiction, Poetry, and Drama. Sixth Edition. New York: HarperCollins.

[5] Charlton, Fraser. 2007. "What are EdMusComs?". FraserWeb. Retrieved From http://www.staff.ncl.ac.uk/fraser.charlton/edmu scom/page12/edmuscom what.html

[6] Wiki Web. 2013. "Edwardian Musical Comedy". 2013. Retrieved From https://en.wikipedia.org/wiki/Edwardian music al comedies

[7] Wilmeth, Don B \& Bigsby, Christopher, ed. 1999. The Cambridge History of American Theatre: Vol 2, 1870-1945. Cambridge: Cambridge University Press.

[8] "What is a silent movie?". 2013. Answers website. Mar 14, 2013. From http://wiki.answers.com/Q/What is a silent movie

[9] "1920's Movies". 2005. 1920-30.com website. Mar 14, 2013. from http://www.1920$30 . \mathrm{com} /$ movies/

[10] "Charlie, Chaplin: Overview of His Life". 1918. Charlie Chaplin Official Website. Mar 16, 2013. From http://www.charliechaplin.com/en/biography/a rticles/21-Overview-of-His-Life

[11] "History of English Drama." 2013. The Iloveindia website. Mar 15 2013, 02:53 from http://lifestyle.iloveindia.com/lounge/50-thingsgirls-wish-guys-knew-13207.html

[12] Dietrich, Richard Farr. 2000. British and Irish Drama 1890 to 1950: A Critical History. Online version. Boston: Twayne Publishers. 